\title{
Barriers in health care to breast cancer: perception of women*
}

\author{
BARREIRAS NA ATENÇÃO EM SAÚDE AO CÂNCER DE MAMA: PERCEPÇÃO DE MULHERES \\ BARRERAS EN LAATENCIÓN EN SALUD EN CASOS DE CÁNCER DE MAMA: PERCEPCIÓN \\ DE LAS MUJERES
}

\section{Leila Luiza Conceição Gonçalves ${ }^{1}$, Gabriela Lima Travassos ${ }^{2}$, Ana Maria de Almeida ${ }^{3}$, Alzira Maria D’Ávila Nery Guimarães ${ }^{4}$, Cristiane Franca Lisboa Gois ${ }^{4}$}

\begin{abstract}
Objective: Identifying the barriers in the access to health care to breast cancer perceived by women undergoing chemotherapy. Method: An exploratory descriptive study. The sample consisted of 58 women with breast cancer receiving chemotherapy and registered in the public oncology ambulatory of Aracaju-Sergipe. Data collection was carried out between October 2011 and March 2012 by semistructured interviews, and data were processed using the SPSS, version 17. Results: Among the interviewed women, 37 (63.8\%) reported at least a barrier in the trajectory of care for breast cancer. The organizational and health services barriers were the most reported in the periods of investigation and treatment of breast cancer. Conclusion: In face of these findings, the barriers should be considered in public health policies and programs for the control of breast cancer in Sergipe.
\end{abstract}

\section{DESCRIPTORS}

Women

Breast neoplasms

Health Services Accessibility

Delayed diagnosis

Oncology nursing

\section{RESUMO}

Objetivo: Identificar as barreiras no acesso à atenção em saúde ao câncer de mama, percebidas por mulheres em tratamento quimioterápico. Método: Estudo descritivo-exploratório. A amostra foi constituída por 58 mulheres com câncer de mama em quimioterapia, cadastradas no ambulatório público de oncologia de AracajuSergipe. A coleta dos dados foi realizada entre outubro de 2011 e março de 2012, por entrevista semiestruturada, e os dados foram processados no software SPSS, versão 17. Resultados: Entre as entrevistadas 37 mulheres $(63,8 \%)$ referiram ter, ao menos, uma barreira na trajetória de cuidado ao câncer de mama. As barreiras organizacionais ou dos serviços de saúde foram as mais citadas nos períodos de investigação e tratamento do câncer de mama. Conclusão: Diante destas constatações, as barreiras devem ser consideradas nas políticas públicas de saúde e nos programas de controle do câncer de mama em Sergipe.

\author{
DESCRITORES \\ Mulheres \\ Neoplasias da mama \\ Acesso aos Serviços de Saúde \\ Diagnóstico tardio \\ Enfermagem oncológica
}

\section{RESUMEN}

Objetivo: Identificar las barreras en el acceso a la atención en salud percibidos por mujeres con cáncer de mama en tratamiento quimioterapéutico. Método: Estudio descriptivo- exploratorio, cuya muestra estuvo constituida por 58 mujeres con cáncer de mama en quimioterapia inscritas en el servicio ambulatorio público de oncología de Aracaju-Sergipe. La recolección de datos fue realizada entre octubre de 2011 a marzo de 2012, por medio de entrevistas semi-estructuradas. Los datos fueron procesados en el software SPSS, versión 17. Resultados: Entre las entrevistadas, 37 mujeres $(63,8 \%)$ relataron haber enfrentado por lo menos una barrera en la trayectoria de cuidado del cáncer de mama. Las barreras organizacionales o de los servicios de salud fueron las más citadas en los periodos de investigación y tratamiento del cáncer de mama. Conclusión: Las barreras deben ser consideradas en las políticas públicas de salud y de los programas de control del cáncer de mama en Sergipe.

\author{
DESCRIPTORES \\ Mujeres \\ Neoplasías de la mama \\ Acceso a los Servicios de Salud \\ Diagnóstico tardío \\ Enfermería oncológica
}

\footnotetext{
* Excerpted from the project "Mulheres sergipanas com câncer de mama: trajetória nos serviços de saúde e qualidade de vida", Oswaldo Leite's Center of Oncology of the Hospital de Urgência e Emergência of Sergipe, 2011-2012. ${ }^{1}$ Assistant Professor of the Department of Nursing, Universidade Federal de Sergipe, Aracaju, SE, Brazil. leilaluiza@globo.com ${ }^{2}$ Nurse by the Department of Nursing, Universidade Federal de Sergipe, Aracaju, SE, Brazil. ${ }^{3}$ Associate Professor, School of Nursing of Ribeirão Preto, Universidade de São Paulo, Ribeirão Preto, SP, Brazil. ${ }^{4}$ Adjunct Professor, Department of Nursing,
} Universidade Federal de Sergipe, Aracaju, SE, Brazil.

$\begin{aligned} \text { Rev Esc Enferm USP } & \text { Received: } 10 / 04 / 2013 \\ \text { 2014; 48(3):394-400 } & \text { Approved: } 03 / 27 / 2014\end{aligned}$




\section{INTRODUCTION}

Breast cancer has become a public health problem worldwide. In 2008, the estimate was of 1,380 new cases and 458,000 deaths from breast cancer. Among these, approximately $59 \%$ occurred in countries of low and middle income $^{(1)}$. Most cases diagnosed in developing countries are in more advanced stages of the disease, which complicates treatment ${ }^{(2-5)}$. Barriers to access to health services, incomplete or missing information, difficulties in infrastructure, socioeconomic, ethnic and geographical conditions are some of the problems that lead to delay in diagnosis, both from other diseases as neoplasms ${ }^{(3,5)}$.

Breast cancer, when detected at early stages, has the best prognosis and ensures lower costs to the health system ${ }^{(6)}$. Due to do this fact, the access to health services is of paramount importance, and goes beyond the mere availability of resources, resulting from a combination of factors, such as favorable geography, supply of services, cultural influence and the removal of economic barriers $^{(7-9)}$.

The delay in diagnosis and treatment implementation may be related to several barriers found during the search for health care ${ }^{(9-10)}$ such as age, gender, education, place of residence, ethnic group, working conditions, low financial status, lack of health insurance, among other factors that detain the diagnosis and care of the disease ${ }^{(3,5,11)}$.

National and international studies recognize the delay in health care to breast cancer as the leading cause of high female mortality from this neoplasm ${ }^{(12-16)}$. As a result, the barriers to access to health care have been studied in several continents such as Latin America, USA, Europe, Asia and Africa, to better understand this phenomenon ${ }^{(10,17-22)}$. However, little is known about the barriers faced in accessing health care to breast cancer in Brazil.

The results of this study may help programs, regulatory systems and assistance, and services flowcharts by understanding the factors that hinder health care in cases of breast cancer, leading to delays in the service and diagnosis at advanced stages ${ }^{(15)}$. It is noteworthy that these factors vary in each region ${ }^{(13)}$.

This study aimed to identify the barriers in the access to health care to breast cancer perceived by women undergoing chemotherapy.

\section{METHOD}

Study of descriptive and exploratory character, carried out in the public oncology ambulatory of the state of Sergipe, located in the city of Aracaju.

The study population consisted of women diagnosed with breast cancer, residents in the state of Sergipe, who had started neoadjuvant or adjuvant chemotherapy in the aforementioned oncology center between 01/08/2011 and $31 / 03 / 2012$. Were excluded of the study the women residing in other states when detecting the change in the breast, those aged under 18 years, and those who had difficulty with understanding and answering the questions of the interview for data collection.

Seventy-eight women diagnosed with breast cancer were identified by a search in the registry of patients, chemotherapy schedule, medical records and telephone contact during the period from $01 / 10 / 2011$ to $31 / 03 / 2012$. Among these, 69 were found in the oncology service, ten were excluded for not meeting the inclusion criteria and a woman refused to participate, resulting in a sample of 58 women.

The interview took place in the waiting room or in the chemotherapy administration room either due to the unavailability of a reserved place at the institution, or the request of the woman. For quality control and better use of the information, women were asked for permission to record the interview with a digital recorder after they agreed to participate and signed the consent form.

For data collection, was used a semistructured interview script developed by the authors, based on the consensus document for breast cancer control of the Ministry of Health ${ }^{(4)}$ and the Clinical practice guidelines in oncology: breast cancer ${ }^{(23)}$, which was content-validated by experts in the subject. The instrument contained questions that addressed information about the following: identification, sociodemographic profile, regarding aspects of the discovery, diagnosis and treatment of breast cancer, the barriers and facilities in access to health services. The open questions related to barriers and facilities in the trajectory of care for breast cancer were adapted from a study carried out in Quebec, Canada(24).

The trajectory of care for breast cancer was explored in three chronological periods: the period of detection, defined between the time when the woman identified any sign and symptom of change in the breast and the first consultation with the health professional; the investigation period, defined as the interval of time between the beginning of investigation and medical diagnosis; and the treatment period, the interval of time between the beginning and end of treatment ${ }^{(24)}$.

The barriers were conceptualized as events that hindered the access of women to health services while dealing with the case of breast cancer, from the identification of signs and symptoms until diagnosis and initiation of treatment. The responsible for the barriers were the women, family, friends, health professionals, the institution or service.

The data collection period was from October 2011 to March 2012, and the information was entered into a database organized in EPI INFO, version 3.2.1. For data analysis, was used the SPSS, version 17. It is noteworthy that the information from the open questions were coded before typing in the database. A descriptive analysis of 
simple frequency was done for the distribution of barriers and those responsible for them. It is important to highlight that during the coding of the reports it was identified that women had reported one or more barriers and responsible people/institutions. For the other variables were calculated the percentage frequencies.

The project was approved by the Ethics Committee in Research of the Universidade Federal de Sergipe, under Certificate of Presentation for Ethical Appreciation (Certificado de Apresentação para Apreciação Ética) - CAAE number 0196.0.107.000-1. Women were previously asked to participate in the study and informed about its objectives and ethical issues. In case of agreement, they signed the Informed Consent Form. The development of the study met the national and international standards of ethics in research involving human beings.

\section{RESULTS}

In the study sample, the mean age was 53.5 years; 42 (72.4\%) women declared themselves to be brown; 32 (55.2\%) were married; 12 (20.7\%) were illiterate; 23 (39.7\%) were classified as belonging to class D, according to the Economic Classification Criterion Brazil (Critério de Classificação Econômica Brasil) - CCEB ${ }^{(25)}, 39$ (67.2\%) lived in municipalities outside the metropolitan region of Aracaju.

The barriers and those responsible for it were identified through open questions, which allowed women to report more than one of them, according to their perception. Among the respondents, 37 (63.8\%) women reported at least one barrier during the trajectory of care for breast cancer. Five of these women have reported barriers and those responsible for it only in the detection period, nine in the period of investigation, twelve in the treatment period and eleven women have reported it in more than one period. The period of treatment of breast cancer was the one with most references of barriers reported by women, totaling 23 (39.6\%).

The sociocultural barriers reported by ten women in the detection period influenced in the decision to seek health care and in the access to consultation, after the discovery of the change in the breast, having the woman herself as the primary responsible, as shown in Table 1.

In the investigation period, 16 women reported barriers. The difficulties perceived by them were related to access to the specialist consultation, and imaging and diagnosis exams due to barriers of the organization or the health services. The Municipal Secretariat or the Health System were the main responsible. Geographical, sociocultural and economic barriers were also mentioned, but less frequently compared with the organizational (Table 2).

The waiting list at health institutions for scheduling appointments, tests or treatment was the organizational barrier most frequently cited in the investigation period.
Table 1 - Barriers and its responsible perceived by women with breast cancer during the detection period - Aracaju, SE, Oct. 2011/Mar. 2012.

\begin{tabular}{lr}
\hline Barriers and its responsible in the period of detection & $\mathbf{n ( \% )}$ \\
\hline Sociocultural barriers & \\
Lack of information about the pathology & $5(38.4)$ \\
Beliefs and taboos surrounding the disease & $2(15.4)$ \\
Fear of diagnosis and interventions & $1(7.7)$ \\
Feelings of anguish and helplessness & $1(7.7)$ \\
Caring for a family member & $1(7.7)$ \\
Other health problems & $1(7.7)$ \\
Shame of showing the body & $1(7.7)$ \\
\hline Economic barriers & $1(7.7)$ \\
$\quad$ Inability to miss work & \\
\hline Responsible & $10(76.9)$ \\
\hline Individual & $3(23.1)$ \\
\hline Patient & \\
Family/friends & \\
\hline
\end{tabular}

Source: Survey data. Note: $(n=10)$.

Table 2 - Barriers and its responsible perceived by women with breast cancer during the investigation period - Aracaju, SE, Oct. 2011/Mar. 2012

\begin{tabular}{|c|c|}
\hline $\begin{array}{l}\text { Barriers and its responsible in the period of } \\
\text { investigation }\end{array}$ & $n(\%)$ \\
\hline \multicolumn{2}{|l|}{ Organizational and health service barriers } \\
\hline $\begin{array}{l}\text { Waiting list for scheduling consultation, tests and } \\
\text { treatments }\end{array}$ & $10(38.6)$ \\
\hline Diagnosis error of a health professional & $3(11.5)$ \\
\hline $\begin{array}{l}\text { Examinations, consultations or unavailable procedu- } \\
\text { res in the SUS* in the municipality of residence }\end{array}$ & $2(7.7)$ \\
\hline Delay in receiving test results & $2(7.7)$ \\
\hline $\begin{array}{l}\text { Postponement of consultation or procedure by the } \\
\text { responsible professional }\end{array}$ & $1(3.8)$ \\
\hline \multicolumn{2}{|l|}{ Geographical barriers } \\
\hline Transfer to another city & $2(7.7)$ \\
\hline $\begin{array}{l}\text { Difficulty of access to transportation provided by } \\
\text { SMS }^{* *}\end{array}$ & $2(7.7)$ \\
\hline \multicolumn{2}{|l|}{ Sociocultural barrier } \\
\hline Lack of information about the pathology & $2(7.7)$ \\
\hline Caring for a family member & $1(3.8)$ \\
\hline \multicolumn{2}{|l|}{ Economic barrier } \\
\hline $\begin{array}{l}\text { Financial difficulty to pay for examinations, diagno- } \\
\text { sis and treatment }\end{array}$ & $1(3.8)$ \\
\hline \multicolumn{2}{|l|}{ Responsible } \\
\hline \multicolumn{2}{|l|}{ Organization or health service or health system } \\
\hline Municipal Secretariat of Health or health system & $13(65.0)$ \\
\hline \multicolumn{2}{|l|}{ Individual } \\
\hline Doctor & $3(15.0)$ \\
\hline Patient & $3(15.0)$ \\
\hline Family/friends & $1(5.0)$ \\
\hline
\end{tabular}


Other organizational barriers mentioned by women also hinder access to health services and continuity in health care (Table 2). Among the 23 women who reported barriers in the treatment period, the most identified difficulties were related to consultation with a specialist, breast surgery and chemotherapy. The organizational or health service barriers were also the most cited, highlighting the waiting list for consultation, tests and treatments. In the perception of women, the hospital and Municipal Secretariats or Health System were responsible for these events ${ }^{(4)}$ (Table 3).

Table 3 - Barriers and its responsible perceived by women with breast cancer during the treatment period - Aracaju, SE, Oct. 2011/Mar. 2012

\begin{tabular}{|c|c|}
\hline $\begin{array}{l}\text { Barriers and its responsible in the period of } \\
\text { treatment }\end{array}$ & $n(\%)$ \\
\hline \multicolumn{2}{|l|}{ Organizational or health service barriers } \\
\hline $\begin{array}{l}\text { Waiting list for scheduling consultation, tests and } \\
\text { treatments }\end{array}$ & 10(38.6) \\
\hline Diagnosis error of a health professional & $3(11.5)$ \\
\hline Delay in receiving test results & 2(7.7) \\
\hline $\begin{array}{l}\text { Examinations, consultations or unavailable procedu- } \\
\text { res in the SUS* in the municipality of residence }\end{array}$ & 2(7.7) \\
\hline $\begin{array}{l}\text { Postponement of consultation or procedure by the } \\
\text { responsible professional }\end{array}$ & $1(3.8)$ \\
\hline \multicolumn{2}{|l|}{ Geographic barriers } \\
\hline $\begin{array}{l}\text { Difficulty of access to transportation provided by } \\
\text { SMS }\end{array}$ & 2(7.7) \\
\hline Transfer to another city & 2(7.7) \\
\hline \multicolumn{2}{|l|}{ Sociocultural barriers } \\
\hline Lack of information about the pathology & 2(7.7) \\
\hline Caring for a family member & $1(3.8)$ \\
\hline \multicolumn{2}{|l|}{ Economic barriers } \\
\hline $\begin{array}{l}\text { Financial difficulty to pay for examinations, diagno- } \\
\text { sis and treatment }\end{array}$ & $1(3.8)$ \\
\hline \multicolumn{2}{|l|}{ Responsible } \\
\hline \multicolumn{2}{|l|}{ Organization or health service or health system } \\
\hline Hospital ou health service & $8(33.3)$ \\
\hline Municipal Secretariat of Health or health system & $4(16.7)$ \\
\hline Health insurance & $1(4.2)$ \\
\hline \multicolumn{2}{|l|}{ Individual } \\
\hline Doctor & $7(29.2)$ \\
\hline Patient & 2(8.2) \\
\hline Family/friends & $1(4.2)$ \\
\hline Nurse & $1(4.2)$ \\
\hline
\end{tabular}

Source: Survey data. Note: $(n=23) .{ }^{*}$ SUS: Unified Health System (Sistema Único de Saúde). ${ }^{* *}$ SMS: Municipal Secretariat of Health (Secretaria Municipal de Saúde)

The geographical barrier, although rarely reported by women in the periods of investigation and treatment, deserves to be highlighted because the transfer to another city and the difficulty of access to transportation provided by the Municipal Secretariat of Health (Secretaria Municipal de Saúde - SMS) were reported, as shown in Tables 2 and 3.

\section{DISCUSSION}

The results of this study show that women perceived barriers in all periods of the trajectory of care for breast cancer, but more frequently in the treatment period. Despite in different social, economic, cultural and health care contexts, a similar situation was reported by 77 women (64\%) of 120 participants in a population study in Quebec, which found at least one barrier during their trajectory of care to breast cancer. The periods of greatest occurrence of barriers were the investigation and treatment ${ }^{(24)}$. The presence of barriers in health care to breast cancer occurs in various contexts and should be recognized and minimized by all actors involved in health care.

In developing countries like Brazil, the mortality rates are related to the lack of resources and infrastructure, hindering the early detection and treatment of cancer. These deficiencies of the service contribute to the detection of cancer in advanced stages, making the cure of breast cancer more difficult, as well as bringing higher costs to the health system ${ }^{(7,10,13)}$.

Among the sociocultural barriers reported by women, the lack of information about the disease stands out. This finding can be explained by the low education of women in the sample, a relevant aspect for early detection of neoplasia because the advanced clinical stage is the most prevalent among women with low education and income $\mathrm{S}^{(5,10,12,26)}$. The lack of knowledge about the disease delays the search for health care, even with the manifestation of important signs and symptoms as the nodule, erythema and edema, because the woman, and sometimes friends and family give different meaning to these changes, minimizing the symptom and not recognizing its seriousness ${ }^{(5,12)}$.

Both the lack of information as social myths created around the pathology are linked to the late diagnosis of breast cancer ${ }^{(5)}$. The first leads to women's vague awareness about the disease, risk factors and severity of symptoms. The generated beliefs are difficult to socially eradicate and once established, may affect the assistance programs of early detection, as for example with the myth that cancer is deadly ${ }^{(5,7)}$.

Although studies report that the fear of the disease or its diagnosis and intervention is one of the major sociocultural barriers, among women this aspect has not been identified ${ }^{(3,5,27)}$.

The organizational barriers reported by women during the period of investigation, should be considered both by managers as by health professionals in the planning and organization of primary care, as well as by continuing education programs. These barriers create delays in diagnosis and treatment implementation ${ }^{(3,10)}$.

For the interviewed women, the difficulty of having the diagnosis of the disease is mostly related to the delay in getting consultations and examinations, with insti- 
tutions and health services as the main responsible. The waiting lists in health institutions for scheduling appointments, tests or treatment was also considered a barrier in regard to accessibility of health care to breast cancer for women who participated in the study in Quebec ${ }^{(24)}$.

It is noteworthy that the period of investigation was the one with highest delay in attention to breast cancer, with 6.5 months on average, confirming that this delay can often be attributed to the slowness of health services ${ }^{(3,28)}$.

Currently, the role of services and health institutions regarding the attention to breast cancer - i.e. how these services are organized and structured to serve people - can significantly affect the periods of investigation and treatment ${ }^{(24,29)}$.

The difficulties in access to consultations and the mammography are due to the low availability of these services. In order to speed the access to cancer care, women with breast cancer and cancer patients pay for consultations, examinations and treatments ${ }^{(12,21)}$.

Thus, inefficient management of health care, disorganized government structure, and little investment in the policy of care to breast cancer do not allow women to receive timely care and effective treatment in the trajectory of health ${ }^{(7,10)}$.

Those responsible for health care must recognize and seek solutions to barriers in the system itself, to improve accessibility during the health trajectory of women. It is necessary to ensure quality in all actions of care for breast cancer (screening tests, diagnostic tests and treatment) ${ }^{(6-7)}$.

All organizational barriers mentioned in the investigation period are repeated in the period of treatment, making the access difficult and compromising the continuity of care. The waiting list in health services for a consultation with the oncologist and the consequent release of chemotherapy, as well as the surgery, were situations frequently reported by women. This shows that the provision of services of treatment is deficient in relation to demand, requiring a waiting list in the service itself. A long interval of time between the end of neoadjuvant chemotherapy and the breast surgery is inappropriate in the oncological standpoint, as there may be a progression of the disease between the maximum response to treatment and the surgery ${ }^{(24)}$.

Although rarely reported by interviewees, the geographical barrier is part of everyday life for many of the women in Sergipe during the trajectory of care for breast cancer, since the services of greater technological density are centralized in the capital.

\section{REFERENCES}

1. International Agency for Research on Cancer; World Health Organization. GLOBOCAN 2008. Cancer Incidence and Mortality Worldwide in 2008 [Internet]. Lyon; 2010 [cited 2013 Aug 09]. Available from: http://www.iarc.fr/en/media-centre/iarcnews/2010/GLOBOCAN2008.pdf
Among the interviewees, 39 women lived in counties outside the metropolitan area of Aracaju and needed to travel frequently to the capital for consultations, examinations and treatment, sometimes paying for transportation costs for themselves and a companion. This type of barrier can influence the access to diagnosis and adherence to oncological treatment. A study carried out in Colombia, aiming to evaluate the equity of access to treatment for breast cancer, indicates the need for detachment to another city as the main barrier to the use of therapeutic interventions $(25.3 \%)^{(11)}$.

The scarcity and bad distribution of reference centers and poor assistance in primary care for breast cancer justify the geographical barriers mentioned by the interviewees. This barrier can cause delay in diagnosis and implementation of treatment for women with symptomatic breast cancer, resulting in higher costs and high female mortality from this neoplasm ${ }^{(12-15)}$.

\section{CONCLUSION}

The study shows that the women in Sergipe face barriers in all periods of the trajectory of care for breast cancer, highlighting the treatment period, which was mentioned the highest number of times. In the search for care, women face geographical, organizational or health service barriers, as well as social, cultural and economic barriers, affecting mainly the search for health care after the discovery of signs and symptoms of change in the breast, and access to consultation with specialist doctors, examinations for diagnosis and treatment. However, organizational or health system barriers, such as waiting lists, unavailability of service and delays in receiving test results, are the most perceived.

Although the results of this study cannot be generalized, they depict, even partially, the northeastern and national contexts regarding the barriers of access to health care to breast cancer and are consistent with other studies. Thus, the development of new studies on the addressed topic is suggested in order to identify other relevant aspects to a broader knowledge of the studied phenomenon.

It is important to emphasize that the results offer significant contributions to understand the barriers and its consequences to health care in breast cancer. It is also useful for health managers and professionals, especially in nursing, due to their involvement in attention to breast cancer since the early detection until the high complexity treatment. Moreover, only few studies on the subject were carried out in the northeast region of Brazil.
2. Brasil. Ministério da Saúde; Instituto Nacional de Câncer. Estimativa 2012: incidência do câncer no Brasil [Internet]. Rio de Janeiro: INCA; 2011 [citado 2013 set. 23]. Disponível em: http://www.inca.gov.br/rbc/n_57/v04/pdf/13_resenha_estimativa2012_incidencia_de_cancer_no_brasil.pdf
Barriers in health care to breast cancer: perception of women Gonçalves LLC, Travassos GL, Almeida AM, Guimarães AMDN, Gois CFL 
3. Unger-Saldaña K, Infante-Castañeda C. Delay of medical care for symptomatic breast cancer: a literature review. Salud Pública Méx. 2009;51(2): 270-85.

4. Brasil. Ministério da Saúde; Instituto Nacional de Câncer. Controle do Câncer de Mama: documento de consenso [Internet]. Rio de Janeiro: INCA; 2004 [citado 2013 set. 23]. Disponível em: http://www1.inca.gov.br/publicacoes/Consensointegra.pdf

5. Nigenda G, Caballero M; González-Robledo ML. Access barriers in early diagnosis of breast cancer in the Federal District and Oaxaca. Salud Pública Méx. 2009;51(2):254-62.

6. Brasil. Ministério da Saúde; Instituto Nacional de Câncer; Prefeitura Municipal de Curitiba. Rastreamento organizado do câncer de mama: a experiência de Curitiba e a parceria com o Instituto Nacional de Câncer [Internet]. Rio de Janeiro: INCA; 2011 [citado 2013 set. 23]. Disponível em: http://www1.inca. gov.br/inca/Arquivos/Rastreamento_organizado_do_cancer_ de_mama.PDF

7. Anderson BO, Yip CH, Ramsey S, Bengoa R, Braun S, Fitch M, et al. Breast cancer in countries with limited resources: health care systems and public policy. Breast J. 2006;12 Suppl 1:S54-69.

8. Miquilin IOC, Marín-León L, Monteiro MI, Corrêa Filho HR. Desigualdades no acesso e uso dos serviços de saúde entre trabalhadores informais e desempregados: análise da PNAD 2008, Brasil. Cad Saúde Pública. 2013;29(7):1392-406.

9. Fekete MC. Estudo da acessibilidade na avaliação dos Serviços de Saúde [Internet]. Belo Horizonte: Secretaria de Estado da Saúde; 1992 [citado 2013 jul. 09]. Disponível em: file:///C:/ Documents\%20and\%20Settings/2509501/Meus\%20documentos/Downloads/texto_gerus_1_I[1].pdf

10. Sharma K, Costas A, Shulman LN, Meara J G. A Systematic review of barriers to breast cancer care in developing countries resulting in delayed patient presentation. J Oncol [Internet]. 2012 [cited 2013 June 09]. Available from: http:// www.ncbi.nlm.nih.gov/pmc/articles/PMC3432397/

11. Charry CL, Roca S, Carrasquilla G. Using biopsy for breast cancer diagnosis: an equity issue? Rev Colombia Med. 2008;39(1):24-32.

12. Rezende MCR, Koch HA, Figueiredo FA, Thuler LCS. Factors leading to delay in obtaining definitive diagnosis of suspicious lesions for breast cancer in a dedicated health unit in Rio de Janeiro. Rev Bras Ginecol Obstet. 2009;31(2):75-81.

13. Trufelli DC, Miranda VC, Santos MBB, Fraile NMP, Pecoroni PG, Gonzaga SFR, Kaliks RRR, Giglio AD. Analysis of delays in diagnosis and treatment of breast cancer patients at a public hospital. Rev Assoc Med Bras. 2008;54(1):72-6.

14. Gebrim LH, Quadros LGA. Breast cancer screening in Brazil. Rev Bras Ginecol Obstet. 2006;28(6):319-23.
15. Ramirez AJ, Westcombe AM, Burgess CC, Sutton S, Littlejohns $P$, Richards MA. Factors predicting delayed presentation of symptomatic breast cancer: a systematic review. Lancet. 1999;353(9159):1127-31.

16. Richards MA, Westcombe AM, Love SB, Littlejohns P, Ramirez AJ. Influence of delay on survival in patients with breast cancer: a systematic review. Lancet. 1999;353(9159):1119-26.

17. Azaiza F, Cohen M, Awad M, Daoud F. Factors associated with low screening for breast cancer in the Palestinian Authority: relations of availability, environmental barriers, and cancer-related fatalism. Cancer. 2010;116(19):4646-55.

18. Kobetz E, Menard J, Barton B, Maldonado JC, Diem J, Auguste $\mathrm{PD}$, et al. Barriers to breast cancer screening among Haitian immigrant women in Little Haiti, Miami. J Immigr Minor Health. 2010;12(4):520-6.

19. Forbes LJ, Atkins L, Thurnham A, Layburn J, Haste F, Ramirez AJ. Breast cancer awareness and barriers to symptomatic presentation among women from different ethnic groups in East London. Br J Cancer. 2011;105(10):1474-9.

20. Akinyemiju TF. Socio-economic and health access determinants of breast and cervical cancer screening in low-income countries: analysis of the World Health Survey. PLoS One [Internet]. 2012 [cited 2013 July 09];7(11):e48834. Available from: http://www.ncbi.nlm.nih.gov/pmc/articles/ PMC3498259/

21. Norsa'adah B, Rahmah MA, Rampal KG, Knight A. Understanding barriers to Malaysian women with breast cancer seeking help. Asian Pac J Cancer Prev. 2012;13(8):3723-30.

22. Ezeome ER. Delays in presentation and treatment of breast cancer in Enugu, Nigeria. Niger J Clin Pract. 2010;13(3):311-6.

23. National Comprehensive Câncer Network. Clinical Practice Guidelines in Oncology: breast cancer. Philadelphia: NCCN; 2011.

24. Bairati I, Fillion L, Meyer FA, Héry C, Larochelle M. Women's perceptions of events impeding or facilitating the detection, investigation and treatment of breast cancer. Eur J Cancer Care (Engl). 2006;15(2):183-93.

25. Associação Brasileira de Empresas de Pesquisa. Critério Padrão de Classificação Econômica Brasil/2008 [Internet]. São Paulo; 2008 [citado 2013 jun. 09]. Disponível em: file:///C:/ Documents\%20and\%20Settings/2509501/Meus\%20documentos/Downloads/07_cceb_2008_em_vigor_em_2008_ base_Ise_2005.pdf

26. Bim CR, Pelloso SM, Carvalho MDB, Previdelli ITS. Early diagnosis of breast and cervical cancer in women from the municipality of Guarapuava, PR, Brazil. Rev Esc Enferm USP [Internet]. 2010 [cited 2013 Aug 14];44(4):940-6. Available from: http://www.scielo.br/pdf/reeusp/v44n4/en_12.pdf 
27. Ferrat E, Le Breton J, Djassibel M, Veerabudun K, Brixi Z, Attali $C$, et al. Understanding barriers to organized breast cancer screening in France: women's perceptions, attitudes, and knowledge. Fam Pract [Internet]. 2013 [cited 2013 May 22];30(4):445-51. Available from: http://fampra.oxfordjournals.org/content/30/4/445.long

28. Dias-da-Costa JS, Olinto MTA, Bassani D, Marchionatti CRE, Bairros FS, Oliveira MLP, et al. Acesso e acolhimento aos usuários em uma unidade de saúde de Porto Alegre, Rio Grande do Sul, Brasil. Cad Saúde Pública, 2007;23(7):1603-12.
29. Tejeda S, Darnell JS, Cho YI, Stolley MR, Markossian TW, Calhoun EA. Patient Barriers to follow-up care for breast and cervical cancer abnormalities. J Women's Health. 2013;22(6):507-17.

30. Mounga V, Maughan E. Breast cancer in Pacific Islander women: overcoming barriers to screening and treatment. Nurs Womens Health. 2012;16(1):26-35. 